\title{
The Comparative Advantage of Aden Port from the Perspective of the Belt and Road Initiative
}

\author{
Ali Hussein Saleh Alghaithi, Wuyi Wang*, Haoyue Xu \\ Business School, Anhui University of Technology, Ma'anshan, China \\ Email: *wwy66@ahut.edu.cn
}

How to cite this paper: Alghaithi, A. H. S., Wang, W. Y., \& Xu, H. Y. (2022). The Comparative Advantage of Aden Port from the Perspective of the Belt and Road Initiative. Open Journal of Social Sciences, 10, 126-146. https://doi.org/10.4236/jss.2022.102008

Received: December 20, 2021

Accepted: February 14, 2022

Published: February 17, 2022

Copyright (อ 2022 by author(s) and Scientific Research Publishing Inc. This work is licensed under the Creative Commons Attribution International License (CC BY 4.0).

http://creativecommons.org/licenses/by/4.0/

\begin{abstract}
The purpose of my study is to demonstrate the comparative advantage of Aden port and the role that might play in the international trade especially through the belt and road initiative that is presented by China, the strong endeavor of the Yemeni government to develop the port, and how Aden port can regain its former significant position. Using the descriptive and comparative methods, this study analyzed the comparative advantage of Aden port and the potential cooperation of Yemen and China in the belt and road initiative through utilizing Aden port in the marine transportation activity. We found out that Aden port needs some further development to be able to bring tremendous benefits to all the countries along the belt and road initiative. Finally, further study on this topic and the role of Aden port in the belt and road is needed due to its strategic location.
\end{abstract}

\section{Keywords \\ Comparative Advantage, Aden Port, The Belt and Road}

\section{Introduction}

Over the past few years, the growth of international trade and its acceleration has pushed many countries to endeavor to seek a comparative advantage in several areas especially in marine transportation which has led to the increasing competitiveness of ports control and management (Guzansky \& Hurvitz 2019). Aden port has been a very important port in the Middle East and probably one of the most significant natural ports in the world. Marco Polo and Ibn Battuta took a tour to Aden port during the $11^{\text {th }}$ and $12^{\text {th }}$ centuries. In 1800 , the development of Aden port began by providing refueling, coal, and water services for steam vessels, where all these services expanded especially after opening the Suez Canal in 1869, which made Aden port in 1950 one of the busiest ports for refu- 
eling ships, and a shopping and trade center in the world (Tikkanen 2000). The location and the natural characteristics of the port made it the target of many ports managing and developing companies such as DP World Ltd., to invest in it. Yemen has six international seaports (Aden Port, Hodeidah Port, Mukalla Port, Al Mokha Port, Saleef Port, and Port Operators) (Henk Engelberts \& Wormmeester, 2020), which are equipped to receive goods and ships and provide cargo, unloading, and storage services. There are also three major maritime ports for the export of oil and liquefied gas (Ras Essa port, Shahr port, and Balhaf port) as well as eight local maritime ports (Editor of Alalam, 2015). The Yemeni Ministry of Transport is the port operator through three corporations, the Yemen Red Sea Ports Corporation (YRSPC) which controls the port of Hodeidah, the port of Ras Issa, and the port of the Mokha; the Yemen Gulf of Aden Ports Corporation (YGAPC) or Yemen port Authority (YPA) controls the port of Aden, Free Zone in Aden, and Balhaf Port; the Yemen Arabian Sea Ports Corporation (YASPC) controls the port of Mukalla, Port of Al Shahr, the port of Nashtoon (Yemen Gulf of Aden Port Corporation, 2019a; Yemen Gulf of Aden Port Corporation, 2015).

Although Yemen has nine active ports, Aden is the most important one which the Yemeni government has been trying to develop port to play a key role in the domestic and national economy by seeking help from other countries who have more experience in the port's development and management (Al-Arhabi, 2008). During my research, I found out that there has not been any work done on this topic or any work related to it. This study is focusing on illustrating the importance of Aden port and the Yemeni governments' efforts to develop the port through seeking international trade cooperation with different countries and especially cooperating more with China by joining in the belt and road initiative. How can the accession of Yemen to the belt and road initiative help the economic and trade cooperation between Yemen and China? Also explaining the potential cooperation between Aden and Gwadar port will bring a benefit to the international trade of the world through easing the transportation of goods and services across the contents (PERGSA, 2001). The rarity of information on this topic presented a new challenge for me. I used descriptions and comparison ways for collecting information on this topic that was challenging for me to find related work. It took me a lot of time and effort to read and search for journal articles, websites, newspapers, and so on. The result eventually was as expected that suggested the cooperation of Yemen with China was the best choice for developing Aden port to play a key role in the belt and road that will benefit not only both countries but rather the world of international trade of goods and services transportations.

\section{Brief Introduction of Aden Port}

\subsection{The History of Aden Port}

The location of Yemen in the south of the Arabian Peninsula has enjoyed the advantages of coasting with regions outside the Arabian Peninsula and its connection within the island. This has played a role in Yemen's subsequent history. 
Aden has become a commercial center for more than 3000 years ago compared to the ports in the area such as Djibouti, Salalah, Jabal Ali and so on that have several hundred years of history. Aden port was mentioned in Ezekiel's book in the Old Testament as one of the cities of commercial interest. Aden was one of the important stations for the spice trade, which had been revived for a whole millennium (Reese, 1937). The city was a small peninsula with few natural resources but its location between Egypt and India made it significantly important in the way of old-world trade.

\subsubsection{In the $18^{\text {th }}$ Century}

In 1838, the British invaded Aden port and some other parts of Lahej province from Sultan Muhsin Bin Fadl. In 1839, the British East India Company and Royal Marines involved the domain to prevent assaults by privateers who were attacking British boats heading to India. The British likewise utilized Aden port as a stopping point for renewing coal and heated water (Goitein, 1384). At this point, we can realize the important location of the port for connecting the western world with the eastern one.

The control of Aden was a strategic rather than commercial occupation to protect the lines of communication with India. With British Somali land on the "horn of Africa", Aden supplied management of the entrance of the Red Sea. After the opening of the Suez Canal in 1869, Britain created protectorates in the hinterland of South Arabia to work as a buffer against the Ottomans who concurred in Yemen (Innes-Robbins, 2009).

\subsubsection{In the $19^{\text {th }}$ and $20^{\text {th }}$ Century}

Aden port was a tanker port that supplied British Petroleum Aden and provided amenities to British organizations and refinery experts. To build and operate the refinery, a large number of skilled professionals and workers were imported. Today, a large portion of the housing built for the laborers is home to well-off locals. To protect the refinery, the British stationed troops in the port of Aden. Protection from the British standard began in 1963. The NLF and the opponent Front for the Liberation of Occupied South Yemen clashed in the port of Aden in 1967 that led the British to withdraw from the zone later that year, leaving the NLF in charge (Mawby, 1967).

Aden was defended by the locally raised Federal Regular Army (FRA) and Federal National Guard (FNG), which were later merged into a single force, the South Arabian Army (SAA). These forces were increasingly distrusted by the British, owing to heavy infiltration by the insurgents. In June 1967, joined by the police, who had also been badly infiltrated, the SAA mutinied and attacked the British, forcing a temporary withdrawal from the Crater area of Aden. During the 1970s, when the Suez Canal was closed and trade via Aden port decreased. During the 1980s, new quays were built to strengthen their aggressive position and meet the demands of the changing marine exchange business. The Aden port could handle a wide range of dry freight and contemporary containers by 
the end of the 1980s (Waters, 2004).

During the union of north and south Yemen in 1990, Aden port thus became the capital of Aden Governate, but not of Yemen as a whole. Since the 1990s, Yemeni ports have seen rapid privatization, increased speculation, and increased assembly output (Yemen Gulf of Aden Port Corporation, 2008). In 1998/99, Aden port achieved recognized record for containerized cargo, with more than 100,000 TEUs handled by the port.

During the early $20^{\text {th }}$ several changes in the region and in Yemen have resulted in the shift from transshipment business to handling a similar number of national imports and export containers. Meanwhile the Ma'alla Terminal handles around 8000 - 10,000 MT/day of bulk, bagged, general and project cargoes. The Aden Gulf Terminal, a private jetty that opened in 2006, provides an additional two large deep water berths for bulk wheat and other cargoes to further increase port capacity (Yemen Gulf of Aden Port Corporation, 2008). The port worked normally at some since until the war that broke in the country in 2015.

From March to July 2015, the Battle of Aden raged between Houthis and loyalists to President Hadi. Water, food, and medical supplies ran short in the city (Armed Conflict Location \& Event Data Project, 2020). On 14 July, the Saudi Army launched an offensive to retake Aden for Hadi's government (Lewis, n.d.). Within three days the Houthis had been removed from the city. Since February 2018, Aden has been seized by the Southern Transitional Council.

\subsection{The Function of the Port}

Port of Aden is one of Yemen's primary and vital oceanic ports in the Gulf of Aden, which is situated in the city of Aden in Yemen. Aden port is one of the biggest natural ports on the planet. The city of Aden derives its importance and vitality through Aden port and the story of Aden as a commercial center for more than 3000 years (Willis, 2009).

\subsubsection{The Location of the Port}

The port is located in the Gulf of Aden on the southern coast of Yemen, on a latitude of 47 degrees and 12 minutes north. The longitude is 58 degrees and 44 minutes east. It is about 95 nautical miles east of Bab Al-Mandab to the southern gate of the Red Sea (Yemen Gulf of Aden Port Corporation, 2015).

The port boundary extends from Ras Abu Qayama at an angle of 166 degrees with a distance of 1.76 miles to a latitude of 12 degrees and 44 minutes north, and a longitude of 44 degrees and 57 minutes to the east. From that place, at an angle of 90 degrees to a latitude of 12 degrees and 42 minutes north, Degrees and zero degrees east, from that place at an angle of (7) degrees and a distance of 3.15 miles to the round island (Danava) (Yemen Gulf of Aden Port Corporation, 2015).

\subsubsection{The Components of the Port}

Aden port consists of two areas the external port and the internal port:

- The area (external port): it is used for only anchoring purposes. It has also 
the port of oil in Aden which is located on the western side of the port.

- The area (inland port): which provides the usual maritime services such as guidance, towing, cargo handling, etc.

The inner and outer ports are separated by the line that extends along the breakwater. These facilities are reached via a transit channel starting halfway between the highlands of the Gulf of the Philippines and Aden (YGAPC, 2008).

\subsubsection{The Structural Port Essentials}

Table 1 shows the areas of the port, however, they are qualified for more expansion, and that illustrates why the government tried to offer this project for international companies specializing in port development and management to come and invest in this project.

\subsubsection{The Productive Port Essentials}

Table 2 demonstrates the current productivity of the port, which is not as it should be in a port that has a very important location in the international shipping line, as we can see, for example, the average of loading and unloading of general cargo, which is 11,900 ton per day, that is a quite low number where it actually can be a lot more than that. It is also able to double and even triple its productivity if it can accept bigger vessels and this would not happen if the port is still in the same situation as it is now.

\subsection{The Climate of the Port}

Aden has a hot desert climate. Although Aden is extremely dry year-round, it is

Table 1. The structural essential of Aden port.

\begin{tabular}{ccc}
\hline Statement & Area & Measurement Unit \\
\hline Maximum Length of the Inner Harbor & 7 & Kilometer \\
Maximum Length of the Outer Harbor & 12 & Kilometer \\
Maximum Width of the Inner Harbor & 5 & Kilometer \\
Maximum Width of the Outer Harbor & 9 & Kilometer \\
Length of Approach Channel & 15 & Meter \\
Depth of Approach Channel & 15 & Meter \\
Total Port Area & 131 & Square Kilometer \\
Water area & 129 & Square Kilometer \\
Land Area & 2 & Square Kilometer \\
Total Container Yards Area & 45 & Hectare \\
Total Open Storage Yards Area & 85 & Hectare \\
Total Closed Storage Yards Area & 4.8 & Hectare
\end{tabular}

Source: The official website of the Aden port

(http://www.portofaden.net/en/site/page/7/Overal\%20Port\%20Description). 
Table 2. The productive essential of Aden port.

\begin{tabular}{ccc}
\hline Statement & Capacity & Quantity/Average \\
\hline $\begin{array}{c}\text { Total Maximum Designed Capacity for } \\
\text { Cargo Handling (accommodating) } \\
\text { Maximum Designed Capacity for } \\
\text { Cargo Handling (TEU) }\end{array}$ & 5.5 & Million Tons/Year \\
$\quad \begin{array}{c}\text { Cargo Handling average } \\
\text { Average of Loading and unloading } \\
\text { of General Cargo }\end{array}$ & $1,000,000$ & TEU/Year \\
$\begin{array}{c}\text { Office working Hours (For Operations 24/24) } \\
\text { Ter }\end{array}$ & $8-12$ & TEU/Day \\
\hline
\end{tabular}

Source: The official website of the Aden port

(http://www.portofaden.net/en/site/page/7/Overal\%20Port\%20Description)

humid throughout the year. This is one of the greatest advantages of the port that makes the ports work during the whole year without any natural disturbing from. Moreover, this climate helps the port to accept any vessels that carry any type of goods on them and provide better services especially, for the international trade vessels that continue their journey to the west. Although the data in Table 3 is quite old, it has not changed since then.

All Yemeni ports including Aden ports have always been playing a very important role in many prospects of Yemeni people's life. And because of the significant location and unique characteristics of these ports, however, the eyes of the world have been targeting these ports and especially Aden port causing some changes of this port and other ports at the same time, particularly in the last couple of years.

\subsection{The Current Situation of Aden Port}

Aden port situation is relatively stable after it went through a difficult time after the civil war that broke up in the country by the end of 2014 (Sallami et al., 2017). The port stopped working for only four months between March and July of 2015 due to the clashes that reached Aden city causing the port to shut down.

According to the chairman of the board of directors of the YGAPC, the container port activity in 2015 was about 178,000 containers after recovering from the war, reaching approximately 465 thousand containers in 2019 as it was the most active port under the government control (Yemen Gulf of Aden Port Corporation, 2019b). While 2020 saw a slight decrease due to the breakout of COVID-19 to 423 thousand containers, followed by a noticeable recovery to reach out to 169 thousand in just four months until April 2021 (Gard, 2021).

Aden port has been working as a major source of income to many of the people living around the city of Aden, but there has been a little change to the situation of the port due to many geopolitical, economic, and political factors that have been influencing this port and the people living near to it and causing these little changes as shown in Figure 1. 
Table 3. The climate of Aden port region.

\begin{tabular}{|c|c|c|c|c|c|c|c|c|c|c|c|c|c|}
\hline Month & Jan & Feb & Mar & Apr & May & Jun & Jul & Aug & Sep & Oct & Nov & Dec & Year \\
\hline Record high & 31.2 & 31.6 & 35.1 & 37.9 & 41.2 & 41.2 & 41.2 & 42.8 & 38.3 & 38.9 & 35.0 & 32.8 & 42.9 \\
\hline${ }^{\circ} \mathrm{C}\left({ }^{\circ} \mathrm{F}\right)$ & $(88.1)$ & $(89.0)$ & (95.1) & (100.1) & (106.1) & (106.1) & (106.1) & (109.1) & (100.9) & $(102.0)$ & $(95.0)$ & $(91.0)$ & (109.1) \\
\hline Average high & 28.4 & 28.6 & 30.2 & 32.2 & 34.1 & 36.6 & 35.9 & 35.3 & 35.4 & 33.0 & 30.7 & 28.9 & 32.4 \\
\hline${ }^{\circ} \mathrm{C}\left({ }^{\circ} \mathrm{F}\right)$ & $(83.2)$ & $(83.5)$ & $(86.4)$ & $(90.0)$ & (93.4) & (97.9) & (96.6) & $(95.5)$ & (95.7) & (91.4) & $(87.3)$ & $(84.0)$ & (90.3) \\
\hline Daily mean & 25.7 & 26.0 & 27.2 & 28.9 & 31.0 & 32.7 & 32.1 & 31.5 & 31.6 & 28.9 & 27.1 & 26.0 & 29.1 \\
\hline${ }^{\circ} \mathrm{C}\left({ }^{\circ} \mathrm{F}\right)$ & $(78.3)$ & $(78.8)$ & $(81.0)$ & $(84.0)$ & $(87.8)$ & (90.9) & $(89.8)$ & $(88.7)$ & $(88.9)$ & $(84.0)$ & $(80.8)$ & $(78.8)$ & (84.4) \\
\hline Average low & 22.6 & 23.2 & 24.0 & 25.6 & 27.7 & 28.8 & 28.0 & 27.5 & 27.8 & 24.6 & 23.2 & 22.9 & 25.5 \\
\hline${ }^{\circ} \mathrm{C}\left({ }^{\circ} \mathrm{F}\right)$ & $(72.7)$ & $(73.8)$ & $(75.2)$ & $(78.1)$ & (81.9) & $(83.8)$ & $(82.4)$ & $(81.5)$ & $(82.0)$ & $(76.3)$ & $(73.8)$ & $(73.2)$ & (77.9) \\
\hline Record low & 15.6 & 17.2 & 18.9 & 18.9 & 21.1 & 23.9 & 22.8 & 23.3 & 25.0 & 18.9 & 18.3 & 16.7 & 15.6 \\
\hline${ }^{\circ} \mathrm{C}\left({ }^{\circ} \mathrm{F}\right)$ & $(60.1)$ & $(63.0)$ & $(66.0)$ & $(66.0)$ & $(70.0)$ & $(75.0)$ & $(73.0)$ & $(73.9)$ & $(77.0)$ & $(66.0)$ & $(64.9)$ & $(62.1)$ & $(60.1)$ \\
\hline Average precipitation & 6 & 3 & 5 & 2 & 1 & 0 & 3 & 3 & 5 & 1 & 3 & 5 & 36 \\
\hline $\mathrm{mm}$ (inches) & $(0.2)$ & $(0.1)$ & $(0.2)$ & $(0.1)$ & $(0.0)$ & $(0)$ & $(0.1)$ & $(0.1)$ & $(0.2)$ & $(0.0)$ & $(0.1)$ & $(0.2)$ & $(1.4)$ \\
\hline $\begin{array}{l}\text { Average precipitation } \\
\text { days }(\geq 0.1 \mathrm{~mm})\end{array}$ & 3 & 2 & 2 & 2 & 1 & 1 & 2 & 2 & 1 & 1 & 1 & 3 & 20 \\
\hline $\begin{array}{l}\text { Average relative } \\
\text { humidity (\%) }\end{array}$ & 72 & 72 & 74 & 74 & 72 & 66 & 65 & 65 & 69 & 68 & 70 & 70 & 70 \\
\hline $\begin{array}{l}\text { Mean monthly } \\
\text { sunshine hours }\end{array}$ & 241.8 & 203.4 & 217.0 & 240.0 & 303.8 & 282.0 & 241.8 & 269.7 & 270.0 & 294.5 & 285.0 & 257.3 & 3106.3 \\
\hline $\begin{array}{c}\text { Mean daily } \\
\text { sunshine hours }\end{array}$ & 7.8 & 7.2 & 7.0 & 8.0 & 9.8 & 9.4 & 7.8 & 8.7 & 9.0 & 9.5 & 9.5 & 8.3 & 8.5 \\
\hline Average rainfall $\mathrm{mm}$ & 6 & 9 & 12 & 11 & 12 & 8 & 30 & 56 & 39 & 18 & 6 & 5 & 17.67 \\
\hline
\end{tabular}

Source: (Jemen, 2021) Klimatafel von Aden-Chormaksar/Jemen. 2021: 50.

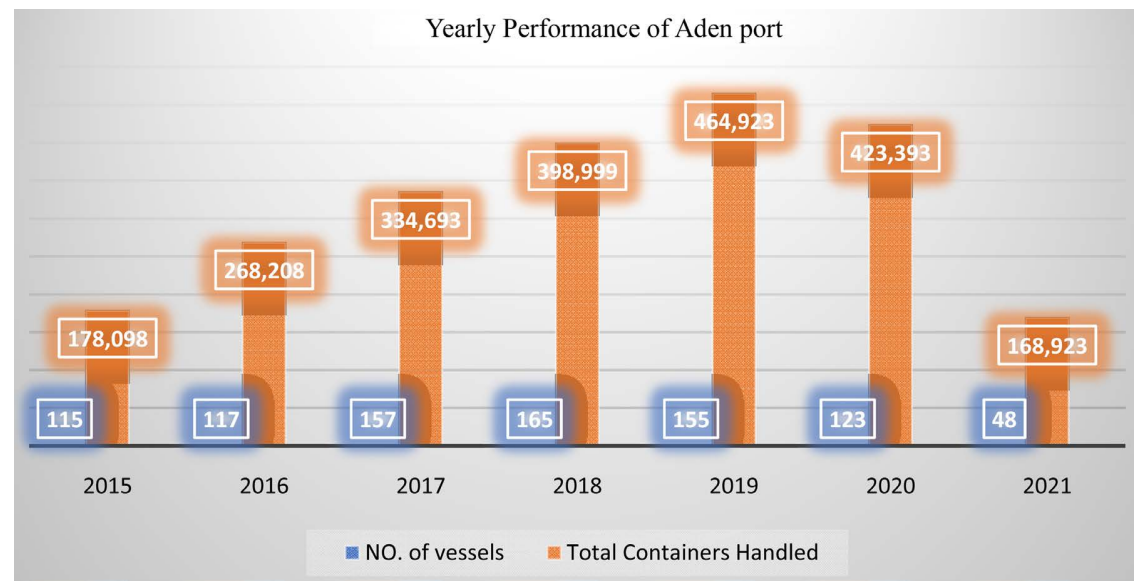

Figure 1. Yearly performance of Aden port. Resource: (Yemen Gulf of Aden Port Corporation, 2019b) data collected since 2015-2021.

Aden port along with other working ports are working regularly with no realized security issues. The limit of working ports may, in any case, be restricted as there might be an absence of fuel supplies and other essential administrations. All vessels endeavoring to enter Yemeni ports should likewise anticipate defer- 
ments and postponements because of the unique section conditions in power and different investigations done by the Saudi Arabian-drove alliance (Gard, 2021).

Aden port is the one that receives a lot of influence since a very early time starting in 2008 after it was being rented out to DP World Corporate to improve the performance of that port, however, the DP World has not complied with what has been agreed upon of developing and expanding the port to be able to work more efficiently. In the next chapter, I will try to illustrate the situation of Aden port before and after being rented to DP World.

\section{The Comparative Advantage of Aden Port from the Perspective of the Belt and Road Initiative}

The ports are playing a significant role in our modern era, this brings many countries to compete and do their best to invest in these ports and led to the establishment of several international corporations that prepare, operate, and manage these ports to be navigable and link them to major maritime lines. This has resulted in a very competitive situation among countries in investing in major commercial ports seeking economic benefits on the one hand, and expansion, control, and influence on the other. Aden port is competing with several other ports in the area such as Salalah, Djibouti which is a rapidly growing port that is very close to Aden port. The port of Aden is one of these considerable ports which have many distinct advantages and characters that attracted the world eyes toward it and that non-other ports in the area or even in the world would rarely be found with such as:

Figure 2 describes the marine ships path and the distance between Aden port or Djibouti port with is the most competitive port to Aden in the regin, and Figure 2 illustrates that it's much more better and easier for the ships to use the services of Aden port and rather than Djibouti port for all the reasons that will be mentioned down bellow. For instance, taking as point $\mathrm{A}$ as the nearest point in the ship's path to Aden port that is approximately $76.16 \mathrm{~km}$, and point $\mathrm{B}$ as the nearest point to Djibouti port that is approximately $138.30 \mathrm{~km}$. This shows that Aden port has an easy accession to by ships than Djibouti port where the distance difference is nearly $62.14 \mathrm{~km}$. The ships can save this distance's fuel and other costs by using Aden port services.

\section{- The long history of the port}

The port has a very long history of more than 3000 years and has been a major regional center; visionaries have always been impressed by the port and the trade opportunities it offers. Marco Polo and Ibn Battuta both noted the prosperity of Aden as a ship-owning center. In 1800, the port of Aden developed and began to provide refueling, coal, and water for steam vessels.

Despite its lengthy history, the port has been impacted by many different civilizations. As a result, the city of the port transformed to be a lovely city with a history that is a mixture of Arabic and British. Simultaneously, Aden's port was undergoing significant social and cultural transformations. 


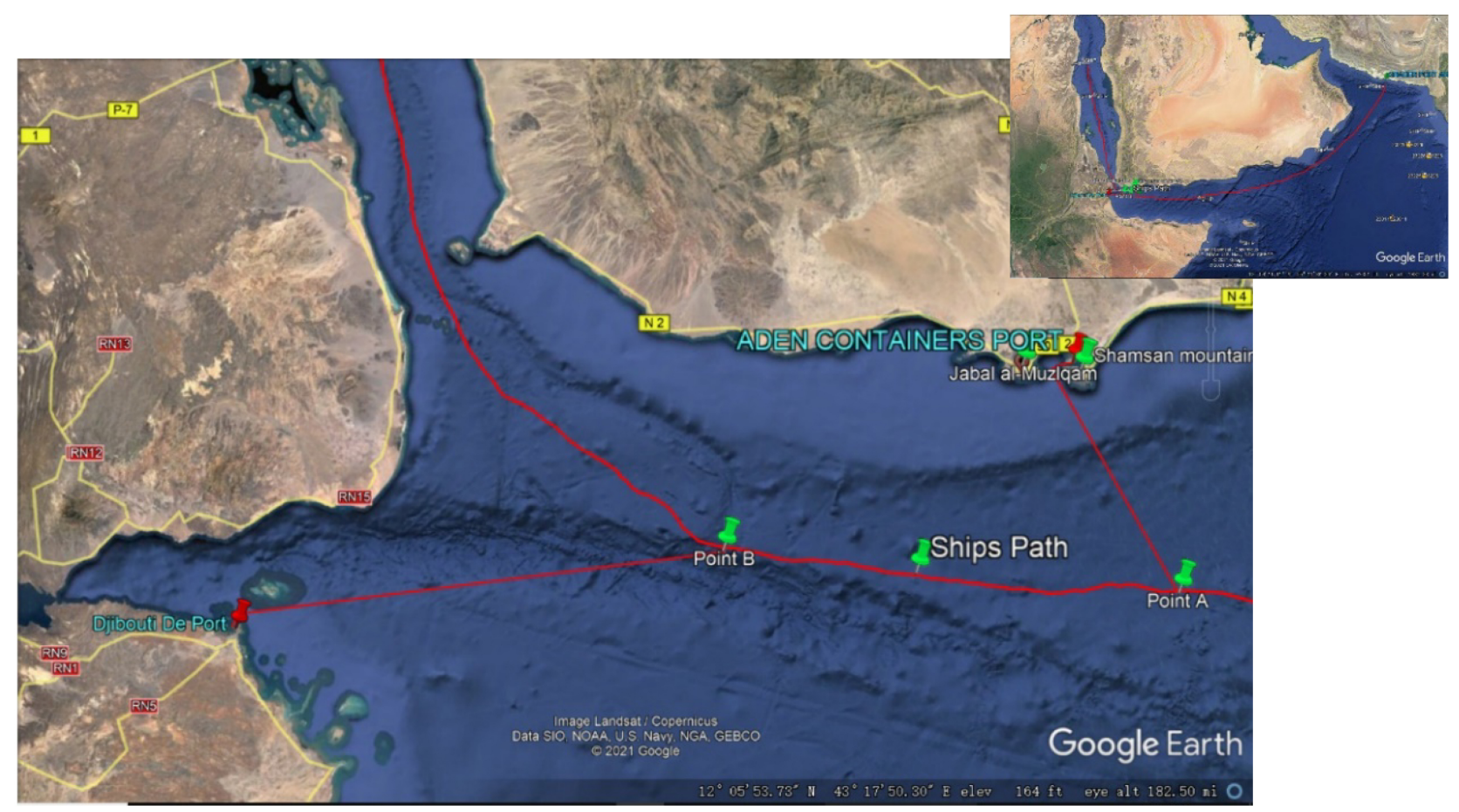

Figure 2. Photo of virtual marine ships paths. Source: Google earth photo taken in July 2021.

\section{- The strategic location of the port}

Figure 2 shows the significant strategic location of the port on the world's substantial trading route via the Suez Canal which made it be considered as a national resource with great potential, known as "Yemen's Gateway to the World" (Willis, 2009). The port is located on the international shipping line linking the east and the west, and it overlooks the Arabian Sea, Bab Al Mandab, and the Gulf of Aden. It is a bit far from the Somali pirates compared to Djibouti port that is much closer to Somalia where they share borders.

The port also represented the base of the colonial expansion of the eastern camp in front of the Soviet Union for ideological expansion. However, The Turks did not overlook the importance of this strategic location of the world and have always extended their control and influence on it because it controls the movement of navigation and international trade and its views of the Horn of Africa (Jaafari, 2014). It is about $7354 \mathrm{~km}$ from NE Europe and $5858 \mathrm{~km}$ from Singapore and very much set to give trans-shipment services to East Africa, the Red Sea, the sub-Continent, and the Gulf. The port is surrounded by two mountains which are Jebel Shamsan range and Jabal al-Muzlqam, which is the natural harbor of the port, adding to it a competitive advantage as a wall against seasonal winds and waves so that it works at any time of year without stopping.

The port also represented the base of the colonial expansion of the eastern camp in front of the Soviet Union for ideological expansion. However, The Turks did not overlook the importance of this strategic location of the world and have always extended their control and influence on it because it controls the movement of navigation and international trade and its views of the Horn of 
Africa (Jaafari, 2014).

\section{- The powerful capacity of the port}

The ability to handle worldly huge container vessels, the Aden Container Terminal (ACT) located at the North Shore of Aden's Inner Harbor was constructed. By March 1999 this facility was commissioned to provide the port with world-class container handling facilities. ACT's productivity reached 500,000 TEU's/year in 2008 and is as predicted to improve significantly in the future (Beydoun \&Bichan, 1969). However, the number decreased after DP World took over the port to reach 180,000 TUE's/year and after breaking the contract with DP World the ACT is recovering back since then to get to 330,000 TEU'S/year by 2017 (Hisham Alhaj-Bisam Alban, n.d.). The port efficiency is classified as one of the best in the world (Al-Eraqi et al., 2008).

\section{- The easy accession to the port}

The convenience of the world's large vessel to park or access the port from the international shipping line in which large ships do not need more than 4 nautical miles only to change their direction to reach the port guidance station (PERGSA, 2001). It is about 4570 miles from NE Europe and 3640 miles from Singapore and very much set to give trans-shipment services to East Africa, the Red Sea, the sub-Continent, and the Gulf. Compared to Djibouti port, it is much easier for a vessel to access Aden port. To illustrate this character of Aden port by calculating the distance the ships take to access both ports, by looking at Figure 2, I assume that the red line is the international shipping line (ships path), and point $\mathrm{A}$ is the nearest point in the ship's path to Aden port that is approximately $76.16 \mathrm{~km}$, and point $B$ is the nearest point to Djibouti port that is approximately $138.30 \mathrm{~km}$. This shows that Aden port has an easy accession to by ships than Djibouti port where the distance difference is nearly $62.14 \mathrm{~km}$. The ships can save this distance's fuel and other costs by using Aden port services.

\section{- The natural harbor and outstanding natural climate of the port}

Aden port is one of the best five natural ports in the world and was considered as the second most important port in the fifties of the last century while it was under British colony (PERSGA, 2002). Table 3 the figures illustrate the magnificent climate of the port where the port has not experienced any significant changes in its climate, that is because of its nature and the two mountains that protect the port from the monsoon.

It enjoys a dry climate with temperatures of around $28^{\circ} \mathrm{C}$ through the winter and $38^{\circ} \mathrm{C}$ during the summer (May-August) (FACEY, 1998). During the year, there is virtually no rainfall in Aden. According to Köppen and Geiger, this climate is classified as BWH. The average annual temperature in Aden is $28.6^{\circ} \mathrm{C}$. Precipitation here averages $43 \mathrm{~mm}$ (CLIMATE-DATA OGR, 2019). This rather convenient climate eases the work for both, the people who work in the port and the type of goods and services they offer.

\section{- The protection of the port}

The port of Aden is placed between the promontories of Aden (Jebel Sham- 
san, $553 \mathrm{~m}$ ) and Little Aden (Jebel Muzalqam, $374 \mathrm{~m}$ ) and is shielded from the NE and SW rainstorm by these slopes and along the northern boundary via land, empowering it to work without confinement all year. The harbor covers a region nearly $8 \mathrm{~nm}$ east-west and $3 \mathrm{~nm}$ north-south (Gladstone et al., 1999). The port of Aden has virtually zero sedimintation in its channels and harbor areas, which means that maintenance dredging is not required.

\section{- The management experience of the port}

The port has a unique experience in port management that was gained through the long history of running the port. It was managed by an independent body representing the various users of the port and it embarks on all kinds of operations of the harbor, including the approval of the tariff in the port and was called "Aden port Trust" (Gavin, 1967). This advantage of the port was proven to be correct in which the country has been suffering from the civil war for more than six-year, however, the port didn't stop its work except for three to four months at most at the beginning of the war in 2015, then it had rapidly come back to function properly as before (Vertin, 2019).

\section{- The connection of the port with the international airport of Aden}

The complementarity in the operation of the port and the airport, and the possibility of connecting them to form a free zone of maritime and air transit, and is due to the distance between Aden international airport and the port of Aden is very close (Alyoum, 2018). The distance between Aden port and the international airport of Aden is $9.2 \mathrm{~km}, 20$ minutes drive by truck, whereas the distance between Djibouti port and Djibouti-Ambouli International Airport is $10.7 \mathrm{~km}$ (International Studies, 2017). This advantage of Aden port can make an integrated system of maritime and air transit trade.

\section{- The size of the port}

The port is quite large, has numerous berths and large warehouses in the southern part, and is greatly expandable in the northern region to include many pavements to handle various types of goods and provide various types of services. The port also has many hangers that can accommodate all kinds of dry and liquid goods, containers, and other types of goods, and there is a wide network of service channels.

Table 4 shows that, the port consists of the outer harbour, providing anchorage areas, the oil harbour at Little Aden on the west side of the bay, and the inner harbour to the east. These harbours are reached by a channel from the entrance mid-way between the promontories. The outer section of the channel has a depth of $15.0 \mathrm{~m}$. From the bifurcation point, a channel heading northwest to the Little Aden oil harbour has a depth of $14.7 \mathrm{~m}$, leading to four berths for oil tankers at depths of between 11.6 and $15.85 \mathrm{~m}$, plus LPG and dry cargo berths and a RoRo berth, all at a depth of $11.0 \mathrm{~m}$ (YGAPC, 2008).

The channel to the inner harbour, leading north east from the bifurcation point, has a least depth of $15.0 \mathrm{~m}$, leading to a turning area, depth $15.0 \mathrm{~m}$, diameter $700 \mathrm{~m}$, south of South of the Aden Container Terminal (ACT). The inner 
Table 4. Size comparison between both ports.

\begin{tabular}{cccc}
\hline & $\begin{array}{c}\text { Aden Port } \\
\text { Water Depth }\end{array}$ & \multicolumn{1}{c}{$\begin{array}{l}\text { Djibouti Port } \\
\text { Water Depth }\end{array}$} \\
\hline Channel: & $36-40$ feet $11-12.2$ meters & Channel: & $31-35$ feet $9.4-10$ meters \\
Cargo Pier: & $31-35$ feet $9.4-10$ meters & Cargo Pier: & $21-25$ feet $6.4-7.6$ meters \\
Anchorage: & $16-20$ feet $4.9-6.1$ meters & Anchorage: & $21-25$ feet $6.4-7.6$ meters \\
Oil Terminal: & $46-50$ feet $14-15.2$ meters & Oil Terminal: & $31-35$ feet $9.4-10$ meters
\end{tabular}

Source: (DP WORLD, 2012; DP WORLD, 2017).

harbour has 10 alongside berths, plus 6 buoy and 3 bunkering (dolphin) berths with depths of between $6.7 \mathrm{~m}$ and $14.0 \mathrm{~m}$ for general cargo, livestock and bulk cargo ships. The smallest berths are at the Ma'alla Wharf, Berths Nos. 5 and 6, with depths of $6.7 \mathrm{~m}$, used by dhows, coastal livestock and cargo vessels. The largest is the Aden Gulf Terminal Berth No. 1 with a depth alongside of $14.0 \mathrm{~m}$. On the north side of the inner harbour, the ACT provides $710 \mathrm{~m}$ of quay, depth alongside $16.0 \mathrm{~m}$. The inner harbour is protected by a short breakwater at Ras Marbut, where the harbour control tower is situated. The Harbour Master's office is in the tower (YGAPC, 2008).

At the eastern end of the inner harbour and turning area, a short channel of depth $11.0 \mathrm{~m}$ leads to the Ma'alla Terminal, with a RoRo berth depth $7.6 \mathrm{~m}$ and 4 container/general/bulk berths of total length $750 \mathrm{~m}$, depth alongside $11.0 \mathrm{~m}$. At the eastern end of this terminal is the Home Trade Quay with two berths, $250 \mathrm{~m}$ long, depth $6.7 \mathrm{~m}$. Within the inner harbour are also a fishing harbour and a ship repair yard (YGAPC, 2008).

\section{- The different services provided by the port}

An integrated service port with a long history of transit and Provision of various types of services to transit vessels such as provision of water, fuel and oil, foodstuffs and consumables, repairs to ships, supply of crews for their needs, cleaning and transport of garbage, and other services work that were and are still being provided to ships at their landing site. The port was also a center to switch the ships' crews. The transit trade of the port accounted for about $90 \%$ of the traffic in the port and still accounts for about $70 \%$ of the total container traffic (YGAPC, 2008).

There are a special oil terminal and a refinery within the port with a large oil storage capacity that can make it the most important port for the oil trade and its immediate derivatives in the region like Rotterdam.

All these special characteristics of the port of Aden such as being protected from strong wind, storms, and other natural disasters, the ability to work all and any time of the year, and so on... has made the port a very important and very crucial part in the international trade world (Armed Conflict Location \& Event Data Project, 2020). The important role that this port has played during the British empire can be regained now and be even more than that through the silk 
road economic belt that the Chinese president Xi Jinping has proposed in Sep 2013. Yemeni government along with its people have realized the important role that the port had played in the past and the role that will play in the future through the Chinese project of "The belt and road" that the Chinese government wants to connect Asia to Africa and Europe. So, the Yemeni government has been attempting to develop the port of Aden so that it can regain its important position in the world. In the following, I will explain the Yemeni government's orientation to develop the port of Aden.

\section{Yemeni Government's Orientation to Promote the Port of Aden}

The orientation of the Yemeni government to develop the port of Aden started ever since the importance of this port had risen. Because of the increasing importance of the port, it had become a crucial part of income for the nation. The port's growth began with the construction of a new pier. Traffic via the port of Aden decreased when the Suez Canal was blocked in the 1970s (Reese, 2018). In the 1980s, new quays were erected to better their competitive position and fulfill the increasing demands of the maritime commerce industry. The port of Aden could handle all forms of dry cargo and contemporary containers by the end of the 1980s.

As a part of the process of upgrading its harbor facilities, YGAPC has arranged a project describing the broadening and extending of the approach channel to the Inner Harbor. The primary reason for this is typically to fulfill the needs of the enormous container ships that are calling or will call, Aden. The current channel is 185 meters wide and 15.0 meters below the chart datum. YGAPC intends to widen the channel to 250 meters and deepen it to $17.0-18.0$ meters underneath the chart datum. The improved channel will have a length of $7.4 \mathrm{~km}$ (4 marine miles) from the inner harbor breakwater to the pilot station and will at that point lead to the existing 700-meter diameter turning area, which will also be deepened. The project requires the removal of some $10 \mathrm{million} / \mathrm{m}^{3}$ of spoil, a few of which can be utilized for recovery work within the inner harbor. Project finance will be sought from international funding sources. YGAPC expects that this improvement will bring adequate width (Sallami et al., 2017).

After unification in 1990, several studies by the British, World Bank, and other consultants came to conclude that Aden is very well placed geographically to improve container trans-shipment services. The "Free Zone Authority" was established in 1990 and a concession agreement to build and operate a new container terminal and an industrial development zone was approved in November 1995 (FACEY, 1998).

By 2005, Yemen has announced the opening of the first phase of a project to rehabilitate and operate bunkering, oil, and water supply facilities at the port of Aden at a total cost of $\$ 41$ million, with private sector investment. The project comprises eight Earth reservoirs and four mountain reservoirs with a pipeline 
network with ship berths and tankers for tanker filling and naval berths, as well as administrative offices and warehouses (Reuter, 2018).

During 2003, the Yemeni government offered the development and operation of Aden port to the international port management corporates to upgrade the port to cope with the standards of the world ports (Gladstone et al., 1999). After a series of negotiations, DP World has signed the contract with the Yemeni government in 2008 to operate the port, unfortunately, DP World didn't implement the terms of the contracts leading the government to break the contract in 2012, in a friendly negotiation.

\section{The Potential Cooperation between Aden Port and China on the Belt and Road Initiative}

The relationship between the port of Aden and China dates back to 1421 when the Chinese Emperor of the Ming Dynasty sent an embassy with presents to the King of Aden. Since then, Yemen and especially the port of Aden-China trade relationship had been going and growing very well, where many vessels going back and forth holding all types of products between the two countries and some of them they just get some fuel and several other services provided by the port and they continue their journey all the way to the west through the red sea (Kamerling \& Van Der Putten, 2011). The cooperation of the two countries can come through two ways:

\subsection{Helping and Investing in the Development of Aden Port}

The Yemeni government is keen to develop the port of Aden in all possible ways, especially using the expertise of international development companies because of the limited possibilities available to the Yemeni government (PERGSA \& Gef, 2002). After breaking the contract with DP World, which was supposed to develop the port as agreed, the Yemeni government had signed an agreement with the Chinese government to develop the port in 2013, and the project was funded with 507 million USD and was supposed to start by 2015 (US Institute of Peace, 2020). However, because of security reasons, the project stopped then (Li, 2009). After the government gets back the control of the city of Aden, the normal situation of the port started again with many efforts of the YGAPC to encourage the Chinese project of developing the port to start up as it is expected of Aden port with its comparative advantages to be a crucial part of the belt and road initiative.

Figure 3 shows the Minister of Industry and Trade, Dr. Mohammed Al-Maitami, signed a memorandum of understanding for Yemen's accession to the Silk Road on Monday, April 25, 2019, with Vice-Chairman of the National Commission for Reform and Development, Mei Ning (Saba, 2017). The accession is based on a new strategic relationship between the two countries in the economic, trade, political, cultural, scientific, and technological fields. It will also revive the historical trade relationship between Yemen and China as Yemen was one of the oldest countries in the history of the Silk Road. 


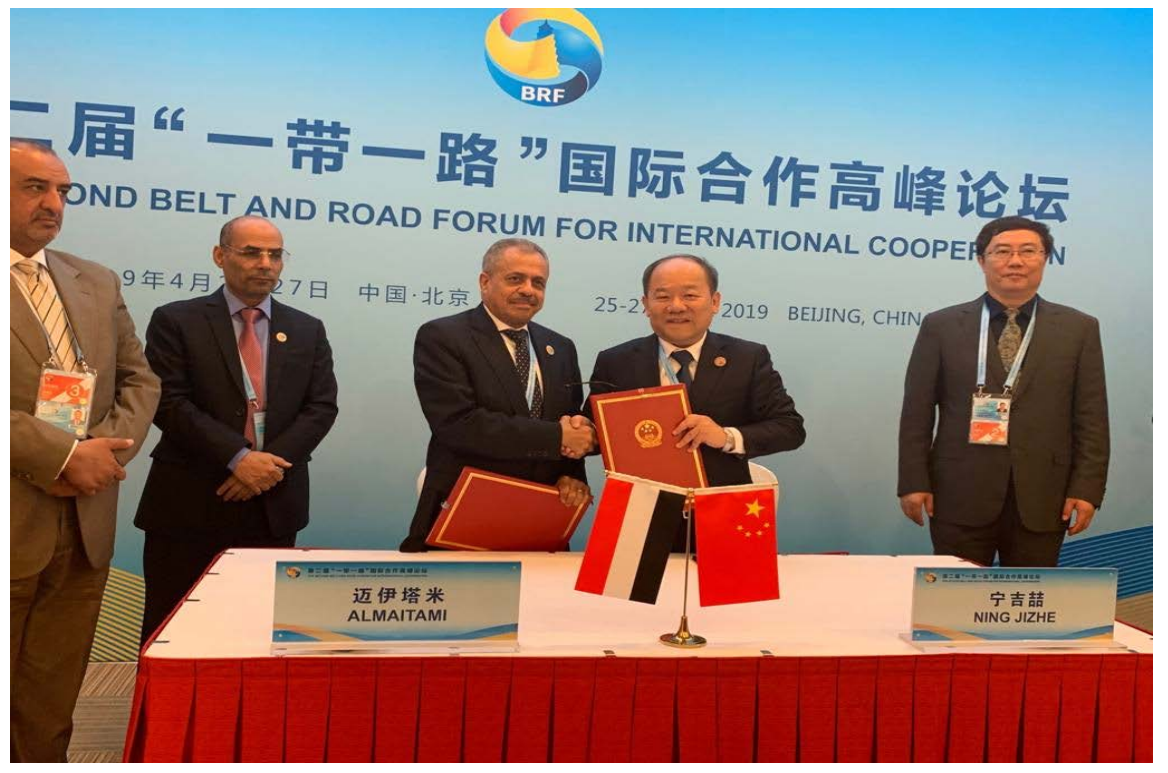

Figure 3. A picture of Yemen joining the belt and road initiative. Resource: This picture is taken from saba.net (Arabic news agency).

The Yemeni government is seeking to activate the agreement between Yemen and China to implement a large Chinese project called the "Belt and Road" or BR which links several countries in one shipping line from China to Europe through the Middle East. The BR that costs over 1 trillion USD in the next ten years, among this, is 705 million USD value of the investment in Aden Port to:

1) Build a new container terminal other than the existing one to increase container storage space to raise the total capacity of the plant from one million containers to 1.5 million containers.

2) Construct a new additional berth of 1000 meters.

3) Deepen the port to 18 meters.

4) Expand the external navigational canal with a length of 7400 meters, a width of 250 meters, a depth of 18 meters, an internal waterway of 3800 meters, a width of 230 meters, and a depth of 18 meters.

According to a report by Depraver, the YGAPC signed an agreement that is funded by China through a loan from the CEI bank to expand and deepen the container terminal in Aden Port in the mid-November 2013 with the Chinese port engineering company in the framework of the visit of President Hadi to China at the time. Economic analysts confirmed that the project, once implemented and completed, will represent a qualitative shift in the navigation work in the port of Aden near the international shipping line (Lin-Greenberg, 2010), as well as returning the port to the international competition map and making it the main gateway to Yemen to the outside world. This project is considered one of the most important economic and investment projects of the YGAPC (Alyoum, 2018).

Figure 4 illustrates that, by using Aden port that is about 4570 miles from NE Europe, 3640 miles from Singapore, and 1371 nautical miles from Gwadar port, 

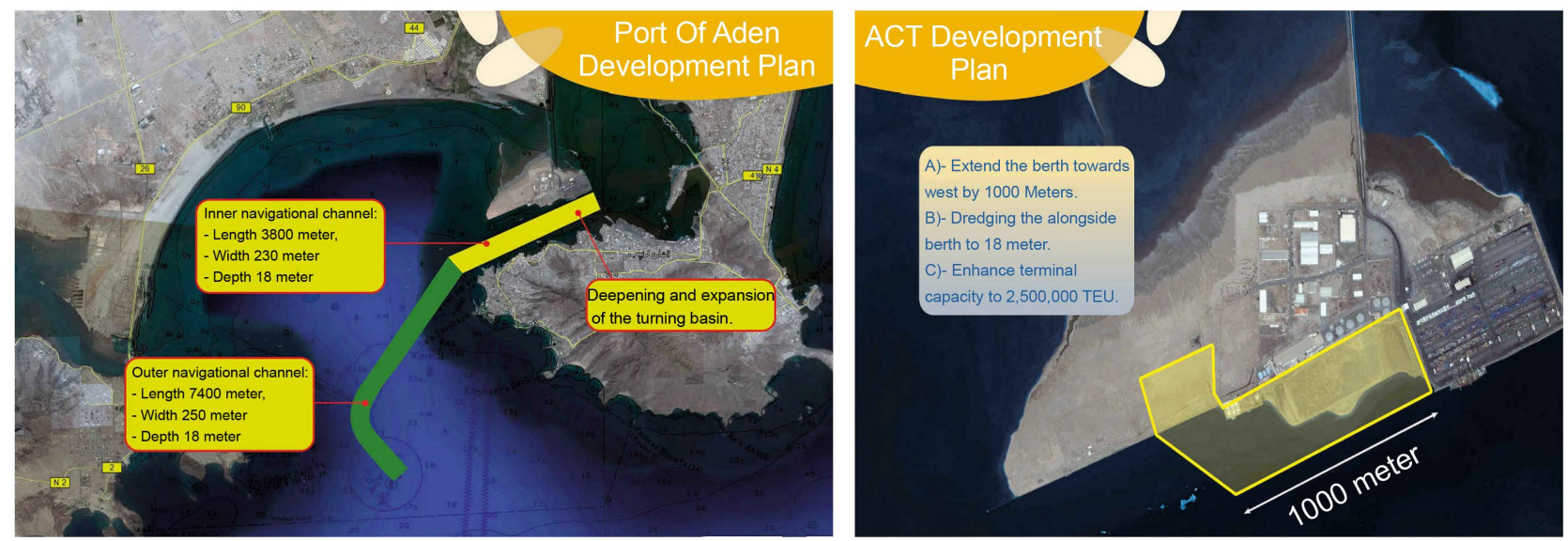

Figure 4. Aden port development plan. Source: taken from google earth on July 2021.

the ships that come from any of the eastern ports such as Colombo port and most importantly Pakistan Gwadar port heading to the Swiss cannel; Aden can be the connecting point. Aden port along with Gwadar port can play a crucial role in the silk road and by then the distance of the marine vessels would shorten, as a result, the ships and vessels would save costs and fuel especially those who are heading to the EU regions because both ports Aden and Gwadar ports are located opposite each other. In brief, Aden port needs some development to double its function and work even better as it was created for.

\subsection{Coordination between Gwadar and Aden Port}

China has invested a lot in Gwadar port, however, Aden port still needs some development to be utilized properly and in a way that would bring more benefit on the one hand to both YGAPC and Gwadar port operating authority and on the other hand to the world of international trade by shorting the way vessels use on the international shipping line, and this benefit would not be found by using other port rather than Aden port. The changes that Aden port need are important for the process of its progress and regaining its position in the world.

Realizing the important location of the port is the connecting point of the western world with the eastern one. The British utilized Aden port as a stopping point for renewing coal and heated water during the 1880s, which was considering Aden port as a strategic port rather than a commercial port, however, the port can serve both purposes. Aden port can be the anchor point between Gwadar Port and the Swiss cannel. Yemen has several ports along its borders, while it has strategic control over the Bab Al-Mandab strait that overlooks all the ships and vessels that travel between the east and west. That means Yemen is a country along the Belt and road that cooperating with it can bring many economic benefits especially in the field of marine transportation and port services due to its unique strategic location and its rich ports.

China and Pakistan have a project named China Pakistan Economic Corridor (CEPC), which is a framework of regional connectivity that will bring another 
way of goods to transfer through road from Xinjiang province in China to $\mathrm{Pa}$ kistan and then to Gwadar port (Afzaal, 2020). The distance between Gwadar port and Aden port is approximately 1371 nautical miles, whereas the distance to Djibouti port is 1525 nautical miles. The idea of the writer states that the goods that travel between the eastern and western world can take the journey as the following:

Figure 5 simplifies the journey of goods starting from any part of China through CEPC to Gwadar port, then to Aden through the Indian Ocean where it can provide refueling, coal, water for steam vessels, and other services provided, after that they can continue their journey to Europe and other destinations.

In short, coordinating between Aden port and Gwadar port is very promising to the belt and road initiative, where it can save the ships time if we consider using any other ports in the area such as Djibouti port as I showed above. The two ports are very close to the international shipping line and that makes it easier for the ships to travel back and forth, furthermore, it is easy to access in and out of the ports. Lastly, I believe both China and Yemen realize the positive outcomes coordinating between the ports would bring not to just both countries but rather all the countries using the marine transportation through the belt.

\section{Conclusion and Recommendations}

\subsection{Conclusion}

This study set out to demonstrate the importance of Aden port and how it was considered to be the second most important natural port in the world in the fifties of the last century, the significant location and unique characteristics attracted many eyes to endeavor to invest in the port.

However, Yemen had experienced an unexpected result from DP World Corporation after the bad performance of the port since it was handed over to them to manage it. The Yemeni government then decided to cancel the contract in 2012 and tried to cooperate with China by signing a cooperation contract to manage and develop the port in 2013 and starting the project in 2015, however since then the contract had not been applied. The important role that this port has played during the British Empire can regain now and be even more than that through the silk road economic belt that the Chinese president Xi Jinping has proposed in Sep. 2013.

This study suggested that the cooperation between Yemen and China can be through two ways, one is developing and investing in Aden port and the other is coordinating between Gwadar and Aden ports in marine transportation. Aden
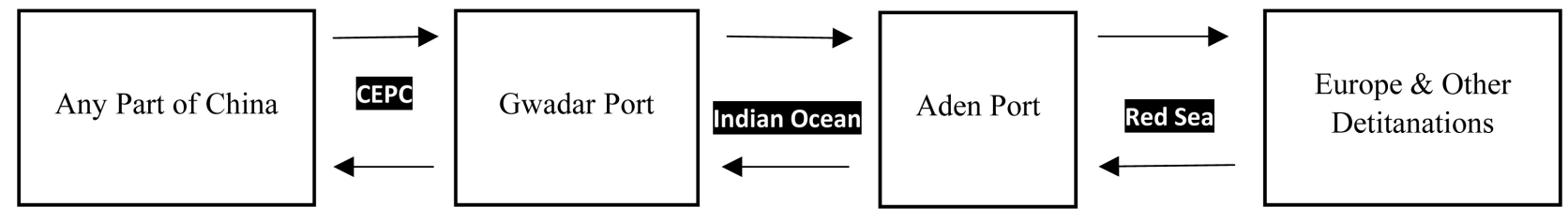

Figure 5. Simple ships Journey illustration. 
port can regain its former position that was during the British empire. The accession of Yemen to the belt and road initiative will be a strong push to more cooperation between Yemen and China, especially through the belt road and the role that Aden port might play in the transportation of goods and services that came from Gwadar port and headed to Suez Canal.

Finally, it is hoped that with this study about Aden port and the belt and road, Aden can bring more cooperation opportunities between Yemen and China that will be not only economical, but also in other aspects benefit the two countries and the world of international trade as a whole.

The deficiency of this study is that it is lack of many studies done in this area, especially Aden port, and the other most important thing is that the belt and road initiative is attached with some political sensitivity as some countries believe which led them to oppose it.

\subsection{Recommendations}

Under the advantages mentioned above, this port is supposed to have a strategic vision to benefit from, maximizing the revenues of the national economy, the city of Aden, its residents, and merchants, and restoring its former leading role in international trade, perhaps the most important things for the port of Aden are: -

1) A strategic vision that defines the goals and objectives of the port of Aden and thus putting medium-and long-term programs to implement this vision with specific timelines, specifying the means and mechanisms required for implementation, including effective marketing plans that explore all the possibilities available in the world to benefit from the port of Aden.

2) The different types of tariffs applicable in the various activities of the port of Aden must be characterized by the discounted prices of competition which makes the shipping companies that are faring in the port of Aden prefer it in all circumstances and conditions.

3) Preventing the monopoly of any company operating container port, allowing open competition in all types of port activities, whether for containers or cargo, allowing the pavements to be leased to shipping companies or other users under certain controls and prices, and allowing the shipping lines to build new sidewalks, so that the port is busy from different companies and beneficiaries.

4) Focus on restoring transit activity and making it the hub of the port activity, while encouraging investors who can use the airport and port for transit purposes.

5) Restore, activate, and permit the provision of various types of services to ships at their landing site or to access these services to their landing site inside or outside the port, with the services being distinct at competitive prices and encouraging the establishment of local companies for this purpose.

\subsection{Recommendations for Further Research}

The present study has been conducted on the comparative advantage of Aden 
port from the perspective of the belt and road initiative. This study also discussed the experience that Aden port had under the management of DP World Ltd. as well as the potential cooperation of Aden port and China through the belt and road initiative. Further study is required as this study is the first study in this field. The required studies might be on:

1) The challenges of the cooperation between Aden port and China on the belt and road.

2) The impact of the emerging ports surrounding the Aden port on the role of Aden port on the belt and road.

On the whole, the paper is too simple to analyze the comparative advantages of Aden port.

A few questions: 1) What are the comparative advantages? Which port compares with? Comparative advantage just is used to analyze the division of international trade. 2) What is the link between BRA and Aden port? 3) Will the war affect the operation of Aden port? If so, how to solve it?

\section{Acknowledgements}

I would first like to thank my thesis advisor teacher Wang Wuyi of International Trade and Business faculty at the Anhui University of Technology. I would also like to extend my thanks to Anhui University of Technology and all the professors and teachers for their help and support not only during my research but rather during my four years of study there.

\section{Conflicts of Interest}

The authors declare no conflicts of interest regarding the publication of this paper.

\section{References}

Afzaal, M. (2020). The China-Pakistan Economic Corridor of the Belt and Road Initiative Concept, Context, and Assessment. Asia Pacific Business Review, 404.

Al-Arhabi, A. K. (2008). Aden: Commercial Capital of Yemen.

Al-Eraqi, A. S., Adli, M., Ahamad, T. K., \& Carlos, P. B. (2008). Efficiency of Middle Eastern and East African Seaports: Application of DEA Using Window Analysis. European Journal of Scientific Research, 23, 597-612.

Alyoum (2018). “Eden Port” Half a Billion Dollar Development Plan. Aden.

Armed Conflict Location \& Event Data Project (2020). The Asifah Brigade. Armed Conflict Location \& Event Data Project.

Beydoun, Z. R., \& Herbert, R. B. (1969). The Geology of Socotra Island, Gulf of Aden. Quarterly Journal of the Geological Society of London, 125, 413-441. https://doi.org/10.1144/gsjgs.125.1.0413

Climate-Data.Ogr. (2019). Climate of Aden.

DP.WORLD (2012). Information and Characteristics about Aden Port Yemen.

DP.WORLD (2017). Information and Characteristics about Djibouti Port Djibouti.

Editor of Alalam (2015) Yemens' Ports and T Heir Importance. 
Facey, R. (1998). The Development of the Port of Aden. The British-Yemeni Society.

Gard (2021). Yemen Ports Situation. Gulf Agency Co. (Yemen) Ltd.

Gavin, R. J. (1967). Aden Under British Rule (1st ed.). 1975 Hurst. GOOGLE BOOK.

Gladstone, W., Tawfiq, N., Nasr, D., Andersen, I., Cheung, C., Drammeh, H. et al. (1999). Sustainable Use of Renewable Resources and Conservation in the Red Sea and Gulf of Aden: Issues, Needs and Strategic Actions. Ocean and Coastal Management, 42, 671-697. https://doi.org/10.1016/S0964-5691(99)00040-X

Goitein, S.D. (1384). From Aden to India. Journal of the Economic and Social History of the Orient, 23, 23.

Guzansky, Y., \& Hurvitz, G. (2019, August 5). A Port Rush: Competition for Control of Trade Routes. Institute for National Security Studies (INSS) Insight No. 1200.

Henk, E., \& Wormmeester, M. (2020). Damage \& Capacity Assessment. United Nations Development Programme.

Hisham, A.-B. A. (n.d.). Aden Commercial Port, Which Represent the Horror of the Neighboring Ports Ristores Its History and Commercial Activities. Aden alghad 2 (Aden Port Commercial Activities).

Innes-Robbins, S. (2009). A Short History of the Aden Emergency. Imperial War Museum 1 .

International Studies (2017). Djibouti : Sovereignty as a Resource. International Studies.

Jaafari, A. (2014). The Full Story of the Destruction of the Port of Aden and the Role of Dubai Ports in Stopping Its Economic Activity. Yemen Press 3 (The State of Aden Under DP World Control).

Jemen (2021). Klimatafel von Aden-Chormaksar/Jemen. Wwtterdienst Deutscher. 50.

Kamerling, S., \& Van Der Putten, F.-P. (2011). An Overseas Naval Presence without Overseas Bases: China's Counter-Piracy Operation in the Gulf of Aden. Journal of Current Chinese Affairs, 40, 119-146. https://doi.org/10.1177/186810261104000405

Lewis, W. C. (n.d.). The Saudi-Arabia Abdrabbuh Mansur Hadi-United Arab Emirates Southern Separatist “Coup” Militia Port of Aden Houthi Iranian Conflict (p. 7). Amazon Digital Services LLC.

Li, M. (2009). China's Gulf of Aden Expedition-Stepping Stone to East Asia. Nanyang Technological University (004).

Lin-Greenberg, E. (2010). Dragon Boats: Assessing China's Anti-Piracy Operations in the Gulf of Aden. Defense and Security Analysis, 26, 213-230.

https://doi.org/10.1080/14751798.2010.488867

Mawby, S. (1967). British Policy in Aden and the Protectorates 1955-67: Last Outpost of a Middle East Empire (British Politics and Society) (1st ed.). Routledge.

PERGSA (Regional Organization for the Conservation of the Environment of the Red Sea and Gulf of Aden), \& GEF (2002). The Regional Organization for the Conservation of the Environment of the Red Sea and Gulf of Aden The Red Sea and Gulf of Aden Regional Network of Marine Protected Areas. PERGSA Technical Report Series, No. 1, 91.

PERGSA (Regional Organization for the Conservation of the Environment of the Red Sea and Gulf of Aden) (2001). Strategic Action Programme for the Red Sea and Gulf of Aden-Country Reports. World Bank.

Reese, S. S. (1937). Aden, the Company and Indian Ocean. Edinburgh University Press.

Reese, S. S. (2018). Hanuman's Tunnel: Collapsing the Space between Hind and Arabia in the Arab Imaginary. In Imperial Muslims: Islam, Community and Authority in the In- 
dian Ocean, 1839-1937 (pp. 17-39). Edinburgh University Press.

Reuter (2018). Yemen Inaugurates Ship Supply Facilities in Aden Port. aljazeera.net.

Saba (2017). Yemen and China Sign Memorandum of Understanding to Join the Silk Road. Saba New.

Sallami, Z., Kassim, Y., Selvaraj, J., Parry, E., \& Winter, G. (2017). Impact of the Armed Conflict of 2015-2016 in Aden on Health Services and the Availability of Medicines. Health, 9, 685-696. https://doi.org/10.4236/health.2017.94049

Tikkanen, A. (2000). Aden: The Old Quarter of Aden, Yemen. Encyclopaedia Britannica.

US Institute of Peace (2020). China's Impact on Conflict and Fragility. JSTOR.

Vertin, Z. (2019). Red Sea Rivalries: The Gulf, the Horn, \& the New Geopolitics of the Red Sea (pp. 1-21). Brookings Doha Center.

Waters, M. E. (2004). World Port Source: Port of Aden.

Willis, J. M. (2009). Making Yemen Indian: Rewriting the Boundaries of Imperial Arabia. International Journal of Middle East Studies, 41, 23-38. https://doi.org/10.1017/S0020743808090089

Yemen Gulf of Aden Port Corporation (2008). Port of Aden History.

Yemen Gulf of Aden Port Corporation (2015). Port of Aden Organization Structure.

Yemen Gulf of Aden Port Corporation (2019a). Aden Port Service Guidelines.

Yemen Gulf of Aden Port Corporation (2019b). Port of Aden. Statistics Data List.

YGAPC (Yemen Gulf of Aden Ports Corporation) (2008). Aden Port, Overall Discription. 